2. Ломброзо Ч. Преступный человек. М., 2005. 880 c. URL: https://asagao.nethouse.ru/static/000/000/298/767/doc/f4/74/af689ff077b64c3e c4a973d1 efb24d8f83e2.pdf (дата звернення: 21. 10. 2020).

3. Масляник O. Деміург 3 Мараморощини. URL: http://zolotapektoral.te.ua/деміург-3-мараморощини/\%20(дата\%20 звернення:\%2019.\%2010.\%202020).

4. Трайста М. Гуцульська душа. Бухарест: RCR Editorial, 2008. 356 с.

5. Швець А. I. Злочин і катарсис: Кримінальний сюжет і проблеми художнього психологізму в прозі Івана Франка / відп. ред. Є. К. Нахлік. Львів, 2003. 236 с.

DOI https://doi.org/10.30525/978-9934-588-90-7-19

\title{
«ХОЧУ ЖИТИ БІЛЯ МОРЯ»: ТЕРАПЕВТИЧНИЙ ВПЛИВ МОРСЬКОГО УЗБЕРЕЖЖЯ У РОМАНІ «СІЛЬ ДЛЯ МОРЯ, АБО БІЛИЙ КИТ» А. НІКУЛІНОЇ
}

\author{
Грищенко О. В. \\ кандидат філологічних наук, \\ дочент кафедри журналістики, \\ проректор з наукової роботи \\ Міжнародний класичний університет імені Пилипа Орлика \\ м. Миколаїв, Україна
}

Сучасна українська письменниця Анастасія Нікуліна написала важливий роман для українського суспільства. Це історія про підлітків із їхніми проблемами, зокрема, суїцидальними настроями. Її дебютна книжка «Сіль для моря, або Білий Кит» (2017) - це спроба зазирнути у внутрішній світ підростаючого покоління, розібратися у проблемних ситуаціях та знайти правильні рішення. У своєму соціальнопсихологічному романі авторка пропонує декілька варіантів виходу із кризової ситуації. Це і підтримка оточуючих, підліткове кохання, нові знайомства, онлайн спілкування тощо. Але, на наш погляд, найцікавішим методом морально-психологічної терапії героїв у романі «Сіль для моря, або Білий Кит» постає лікування морем, або таласотерапія.

За канонами масової літератури авторка використала у сюжеті твору чи не найпривабливіші фабульні моменти: красиве життя заможних дітей, почасти ідеальні портрети, перше кохання, популярність серед однолітків, гаджети тощо. Але за цією красою криються значно 
серйозніші речі, які, на жаль, мають місце в сучасному підлітковому суспільстві: жорстокість, знущання, підлість.

На фоні такого «ідеального» життя вирізняється Ліза, головна героїня роману, яка стає об'єктом посміховищ та постійного кепкування однокласників. Ліза - лялька у руках однолітків, яка втрачає віру в себе та своє життя. Відтак, дівчина задумується над фатальними вчинками. «Я так втомилася бігати. Вони весь час наздоганяють. ... Може, краще, якби мене взагалі не було? I взагалі - я з'явилась на світ помилково? Як чийсь злий жарт. Я ненавиджу цей світ, я себе ненавиджу» [2, с. 39].

Усі свої страхи та переживання, болі та травми головна героїня тримає у собі. Підліток не має вірних друзів, а з батьками постійні конфлікти. Тут дається взнаки пережите трагічне минуле, яке психологічно позначилося як на Лізі, так і ії батьках. Дівчинка у новому місті самотня, вона закрита від принад життя: «... почалися жарти. Спершу просто дурні, потім - образливі. Все почалося з нічого! I я була сама. Я тут тільки сама» [2, с. 39]. Сдине, що рятує героїню, море.

Море та морське узбережжя - основна декорація роману «Сіль для моря, або Білий Кит». Саме тут відбуваються чи не найкульмінаційні події. Разом із тим, у романі на морському узбережжі простежуються характери героїв, психологічні стани, діалоги та монологи, ставлення героїв до суспільства та світу зокрема, зрештою відпочинок та можливість побути на самоті.

Головна героїня сприймає море не як об'єкт відпочинку, а як співрозмовника, єдиного друга, якого не вистачає у повсякденному житті. Тому море Ліза наділяє людськими якостями.

Море має свій голос. Це простір, у якому сконцентровано звуки морських тварин та птахів, суден та людей, вітру та дощу. Лише підкорений морем може чути його різноголосся та відлуння. Шум моря заповнює пустоти, а, отже, діалог із ним, заповнює внутрішню порожнечу. За Г. Башляром, медитація зі «звуками, які шепочуть» стає зрозумілою, коли піддатися фантазії, «уяві варто бути володарем динамічних відповідностей, тоді образи справді починають говорити» [1, с. 267]. Розмова із морем - це лікувально-терапевтична процедура, яка створює певний настрій, а також дає розраду хиткому психологічному стану, спустошеній психіці, почасти і божевіллю.

Наодинці $з$ морем Ліза почувається вільною, довіряє йому свої секрети, говорить із ним. «В дитинстві вона любила розмовляти з морем. Ділитися своїми думками, наспівуючи щось собі під ніс, читати вірші, мріяти, будувати плани. Море завжди було вдячним слухачем. I завжди вміло втішати без зайвих слів, просто одним своїм "ш-ш-ш"» [2, с. 37]. 
На морському узбережжі героїня забуває про шкільних кривдників та родинні сварки.

Море та морське середовище вкрай позитивно впливає на підлітка. Чим частіше Ліза буває біля моря, тим впорядкованішими стають іiі думки, душевні та фізіологічні травми поступово загоюються. Саме на морському узбережжі Ліза аналізує своє життя та намагається його полюбити, розібратися у несправедливостях, вчиться правильно реагувати на однокласників та сварливих батьків. Принагідно важливо, що Ліза не єдина, хто приходить до моря за допомогою.

Якщо розмови із морем розвантажують Лізу психологічно, іiі розум, то плавання у морі - це терапія тіла. Дівчина відчуває цілковиту гармонію зі стихією, умиротворення, свободу. «Коли Ліза вмощувалася на поверхні зручніше, занурювала потилицю у воду, заплющувала очі, розкидала руки й повністю розслаблялася, тоді здавалося, ніби вона не в морі, а в небі, і ширяє в невагомості. За це відчуття легкості Ліза була безмежно вдячна морю. Бо тоді зникали всі образи, всі жалі, все погане» [2, с. 38]. Стихія води вбирає в себе все негативне, відтак доцільно говорити про архетип чистоти. Чиста вода не лише очищає тіло від бруду, а й має цілющі властивості.

У медичній літературі закріпився термін «таласотерапія»- лікування морем, морським кліматом та купаннями. Такі процедури протистоять стресам, дозволяють розслабити тіло, поліпшують стан нервової системи. Корисні фактори таласотерапії значно впливають на тих героїв роману, які періодично навідуються до моря.

У романі «Сіль для моря, або Білий Кит» стихія води відіграє значну роль для потерпілих та фізично й духовно хворих. Це не лише стихія, а й тотальна істота, яка має свої потреби. Це стихія холеричного темпераменту, життєздатна субстанція онтологічної чистоти.

\section{Література:}

1. Башляр Г. Вода и грезы. Опыт о воображении материи / Пер. с фр. Б. М. Скуратова. Москва: Издательство гуманитарной науки, 1998. 268 с.

2. Нікуліна А. Сіль для моря, або Білий Кит. Харків: Віват, 2017. 224 с. 